\title{
The Use of Repeatable Components in Hybrid Models to Enhance Software Project Management Success
}

\author{
Marzanah A. Jabar', Norhayati Mohd. Ali ${ }^{2}$, Yusmadi Yah Jusoh ${ }^{3}$, Salfarina Abdullah ${ }^{4}$, S. Mohanarajah $^{5}$ \\ ${ }^{1,2,3,4}$ Faculty of Computer Science \& Information Technology, University Putra Malaysia, 43400, Serdang, \\ Selangor, Malaysia \\ ${ }^{5}$ Faculty of Computer, Engineering and Technology, Asia Pacific University, Technology Park, Bukit Jalil, \\ 57000, Kuala Lumpur, Malaysia \\ marzanah@upm.edu.my*11, smohan@apu.edu.my ${ }^{5}$
}

Article History: Received: 10 November 2020; Revised: 12 January 2021; Accepted: 27 January 2021; Published online: 05 April 2021

\begin{abstract}
The management of software project development requires a dynamic and reactive environment to meet shorter time-to-market demands to address competition efficently in the software industry. This scenario requires the use of effective and robust methodologieswhere opportunities are not lost due to delays and failures in timely software project deliveries. The Agile Manifesto in 2001 which introduced 4 values and 12 principles was designed to develop and manage software projects in a more suitable and effective way to improvethe success rates of software projects. But, increase in overall success rates are still not significant with failure rates remaining plauteaued at about $30 \%$ over the last 10 years. Hybrids methodologies seem to have worked better as agile hybrid management methodshave shown more promise when compared to pure agile methods with an overall success rate increase of $16 \%$. There is evidence too that by combining agile methodologies with traditional methodologies, there would be a further increase in success rates. Whilst many hybrid methodologies have been suggested and researched, the gaps in the literature review reveal there is a lack of hybrid models that have been empirically developed and studied as second order components. To build a robust hybrid model, it is important to gather the relevant information and careful consuideration must be given to the design of the questionnaireto fit second order components and models must incorporate and provide for the use repeatable ways to test models once the data is collected.This paper presents a review of the current gaps in hybrid methodologies and proposes a questionnaire design that supports the research methodology and empirical study to be undertaken with second order components (Constructs).Further it looks at the design approach in questionnaires which incorporates the use of repeatable constructs and the measures used and emphasizes this as an important ingredient for developing and testing hybrid models in research studies.
\end{abstract}

Keywords:Questionnaire, Design,Traditional, Agile, Methodologies, Repeatable, Hybrid.

\section{Introduction}

Project management as a discipline that is not categorized as an exact science and the primary constructs in a theory are required to be well defined (Gregor, 2006) and provide a clear context in the manner it is used (Eri et al.,2012; Niknazar \& Bourgault, 2017) and how it is queried (Saad et al., 2014; 2016; Alwan et al., 2016; 2017).

Hybrid architecture is a common feature that maintains reactive behaviour in dynamic environments (IskandarIshak et al., 2012; Sidi et al. 2013;Yang, Mao, Yang, \& Liu, 2017). In a similar context, software development activities are managed in dynamic enviroments(Jabar et al., 2014; Schelling \& Pierling, 2015; Gheni et al., 2016)that require reactive approaches (Yang et al., 2017; Sidi et al., 2017; Hussain et al,. 2016)to meet shorter time-to-market demands(Spalek, 2016) and hybrid architectured methodologies have provided opportunities as software project success rate have increased by 16\% (Papadakis \& Tsironis, 2018).

A hybrid software project management methodology is defined as a combination of traditional and agile software development methodologies and philosophies to create a collective interaction of combination patterns and tailoring strategies (Kuhrmann et al., 2018a; Papadakis \& Tsironis, 2018; Hussain et al., 2016).

A recent CHAOS report in 2018 (Figure1) provides evidence of a success percentage hovering between a range of $27 \%-31 \%$ with slight improvements over the years. The report reviwed data from over 50,000 projects software projects which ranged from tiny enhancements to massive systems re-engineering and implementations. The definition used for failure in the CHAOS report was done on failed projects which typically include projects completed but with a very poor quality both in the product and the processes used (Magne Jørgensen, 2014). 


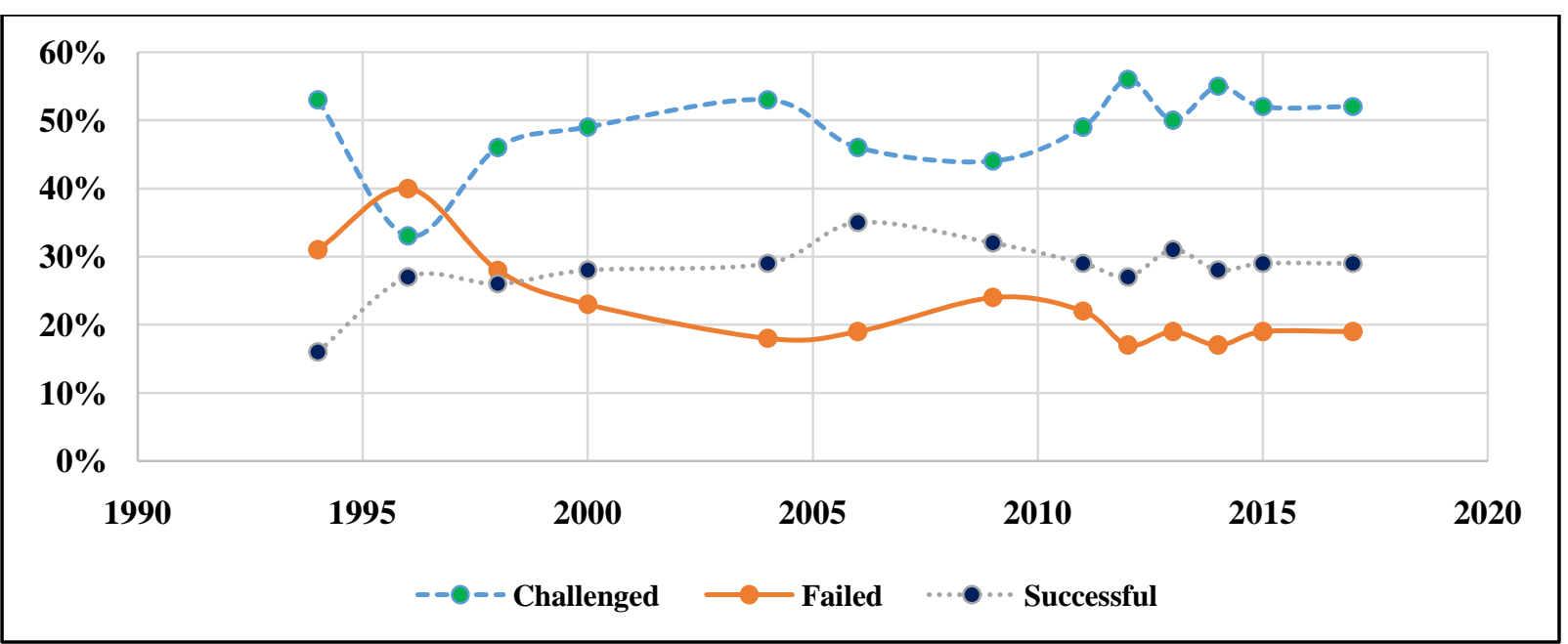

Figure 1.2018 CHAOS Report on IT Software Project Performance

Studies in this area would require an initial and independent look at the traditional and agile software project management methodology characteristics and an eventual review of the combined characteristics through models that support the various concepts and theories.

The study of characteristics can be viewed as the study of indicators in the development of constructs and models and the use of repeated indicators are primarily useful in the hybrid model development to assist in striking a balance between the two methodologies due to similarities and measures of success between the two techniques(Papadakis \& Tsironis, 2018)

Careful consideration is necessary for the design of questionnaires (Roopa S, 2012) which should include the various characteristics as constructs and indicators which use measures and provide for repeatable constructs to study the proposed model in terms of its validity and fit.

\section{Materials and Methods}

A review of the gaps in current traditional, agile and hybrid project success management models reveal that the hybrid architecture that requires a reactive behavior and a dynamic environment is not evident (Table 1). To build efficient hybrid constructs, the gaps in traditional and agile constructs must be combined as gaps in hybrid construct to exist as repeatable gaps when the overall model is tested. Variables should be introduced (also termed as indicators in some research papers) with measures used to formulated the type of questions that will be required in the questionnaires. This fulfils the basic architecture in hybrid models and design of the questionnaire.

Table 1. Current Gaps and Constructs in Traditional, Agile and Hybrid Models

\begin{tabular}{|c|c|c|}
\hline Research Gap in Project Success Models & $\begin{array}{l}\text { Model } \\
\text { Constructs }\end{array}$ & Literature \\
\hline $\begin{array}{ll}\text { - } & \text { Insufficient conditions to meet delivery timely } \\
- & \text { Insufficient studies on adaption } \\
- & \text { Unable to identify quick solutions for small } \\
\text { projects. }\end{array}$ & Traditional & $\begin{array}{l}\text { (Papadopoulos, } \\
\text { Spalek, 2016) }\end{array}$ \\
\hline $\begin{array}{l}\text { - } \begin{array}{l}\text { Ineffective management of tailoring activities } \\
\text { - }\end{array} \text { Unable to identify solutions for large and } \\
\text { complex projects }\end{array}$ & Agile & $\begin{array}{l}\text { (Vedsmand, Kielgast, \& } \\
\text { Cooper, 2016; Wells, } \\
\text { Dalcher, \& Smyth, 2015) }\end{array}$ \\
\hline $\begin{array}{ll}\text { - } & \text { Not managed in a systematic, efficient and } \\
\text { reliable manner for medium and large projects } \\
\text { - } \\
\text { - } \\
\text { - } \\
\text { - } \\
\text { Norporate implementation is limited } \\
\text { - Combination techniques not working well. } \\
\text { dependency. } \\
\text { Benefits not efficiently realized }\end{array}$ & Hybrid & $\begin{array}{l}\text { (Conforto et al., 2016; } \\
\text { Kuhrmann et al., 2018b; } \\
\text { Rauf \& AlGhafees, 2015) }\end{array}$ \\
\hline
\end{tabular}


A summary of the gaps are provided in Table 1. As hybrid models have a $16 \%$ increase in success rate than pure models(Carvalho et al., 2012), a new hybrid project management model was developed and proposed to close some of the gaps instead of developing a new pure traditional or a new pure agile model.

Table 2. Questionnaire Design for the 4 Components

\begin{tabular}{|c|c|c|}
\hline Component (Constructs) & Questions & Literature \\
\hline & $\begin{array}{l}\text { Ordinal (Likert } \\
\text { Scale) -Items }\end{array}$ & \\
\hline 1-Traditional (T) & 11 & $\begin{array}{l}\text { (Jørgensen, 2016;Gill et al., 2016; Takeomi Imani, } \\
\text { Masaru Nakano, 2017) }\end{array}$ \\
\hline 2-Agile (A) & 9 & $\begin{array}{l}\text { (Fontana et al., 2015; Jørgensen, 2016; Takeomi Imani, } \\
\text { Masaru Nakano, 2017) }\end{array}$ \\
\hline $\begin{array}{l}\text { 3-Hybrid }(\mathrm{T}+\mathrm{A})) \\
\text { (Repeated from } 1+2 \\
\text { above) }\end{array}$ & 20 & $\begin{array}{l}\text { (Serrador \& Pinto, 2015; Cooper, 2016; Davis, } \\
\text { 2017; Takeomi Imani, Masaru Nakano, 2017) }\end{array}$ \\
\hline 4- Project Success (S) & 9 & $\begin{array}{l}\text { (Dao, Kermanshachi, Shane, Anderson, \& Hare, 2016; } \\
\text { Takeomi Imani, Masaru Nakano, 2017; Wood \& Ashton, } \\
\text { 2010; Nguyen et al., 2018) }\end{array}$ \\
\hline
\end{tabular}

An instrument in the form of a questionnaire was designed with the set of indicators that were used as measures in the model. The design comprised a set of 4 components (constructs) with ordinal (Likert-scale) questions for each component which ensured repeatable indicators could be used for analysis (see figure 3 ). This is summarized in Table 2.

The conceptual representation of hybrid components (constructs) is provided in Figure 2. Items in $1^{\text {st }}$ order construct will be represented as repeated items in the $2^{\text {nd }}$ order construct (Wilson \& Henseler, 2007).

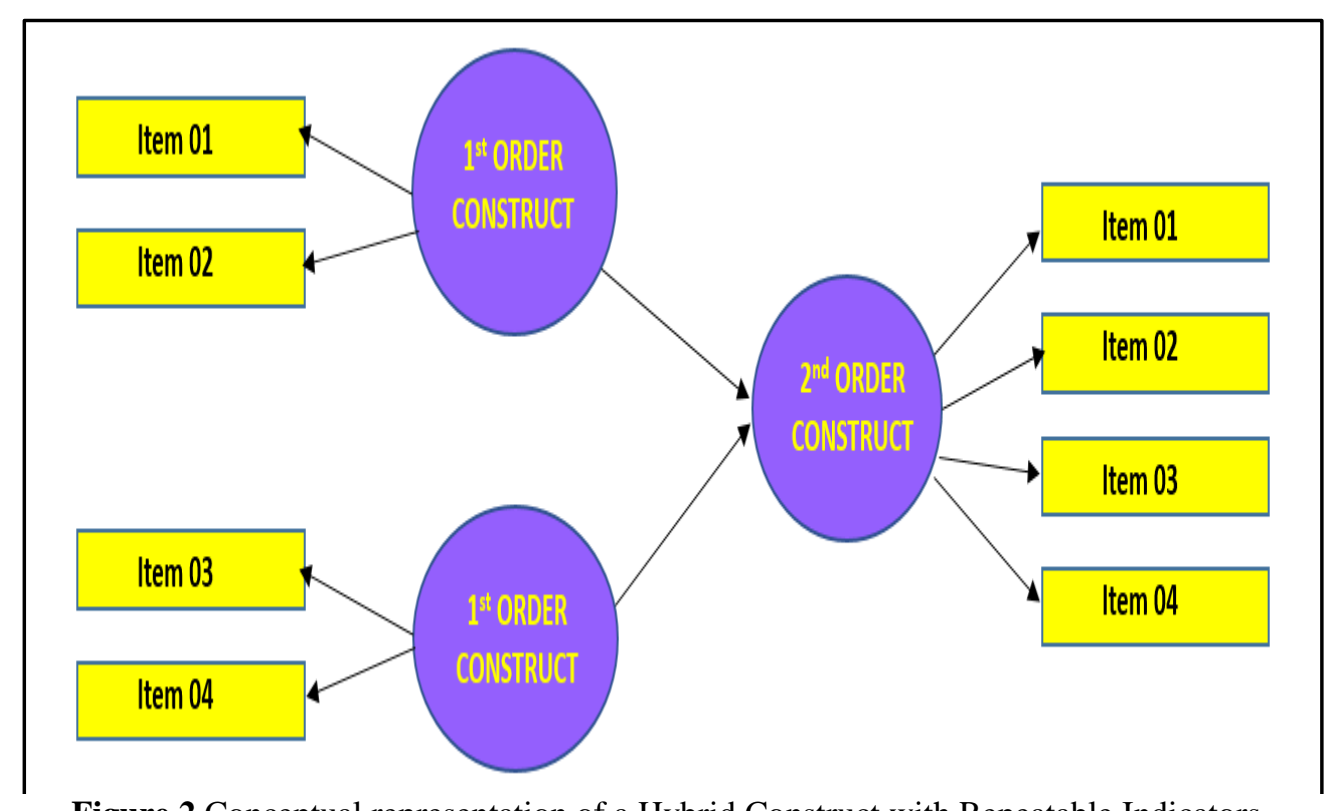

Figure 2.Conceptual representation of a Hybrid Construct with Repeatable Indicators

The agile hybrid proposed model was also developed from existing traditional and agile characteristics as combined for the hybrid construct to address the gaps. The proposed model and the measurement indicators are provided in Figure 3.Due to a large number of indicators the abbreviation ' 01 to $\mathrm{nn}$ ' is used, e.g. T01....Tnn for Traditional Model indicators. 


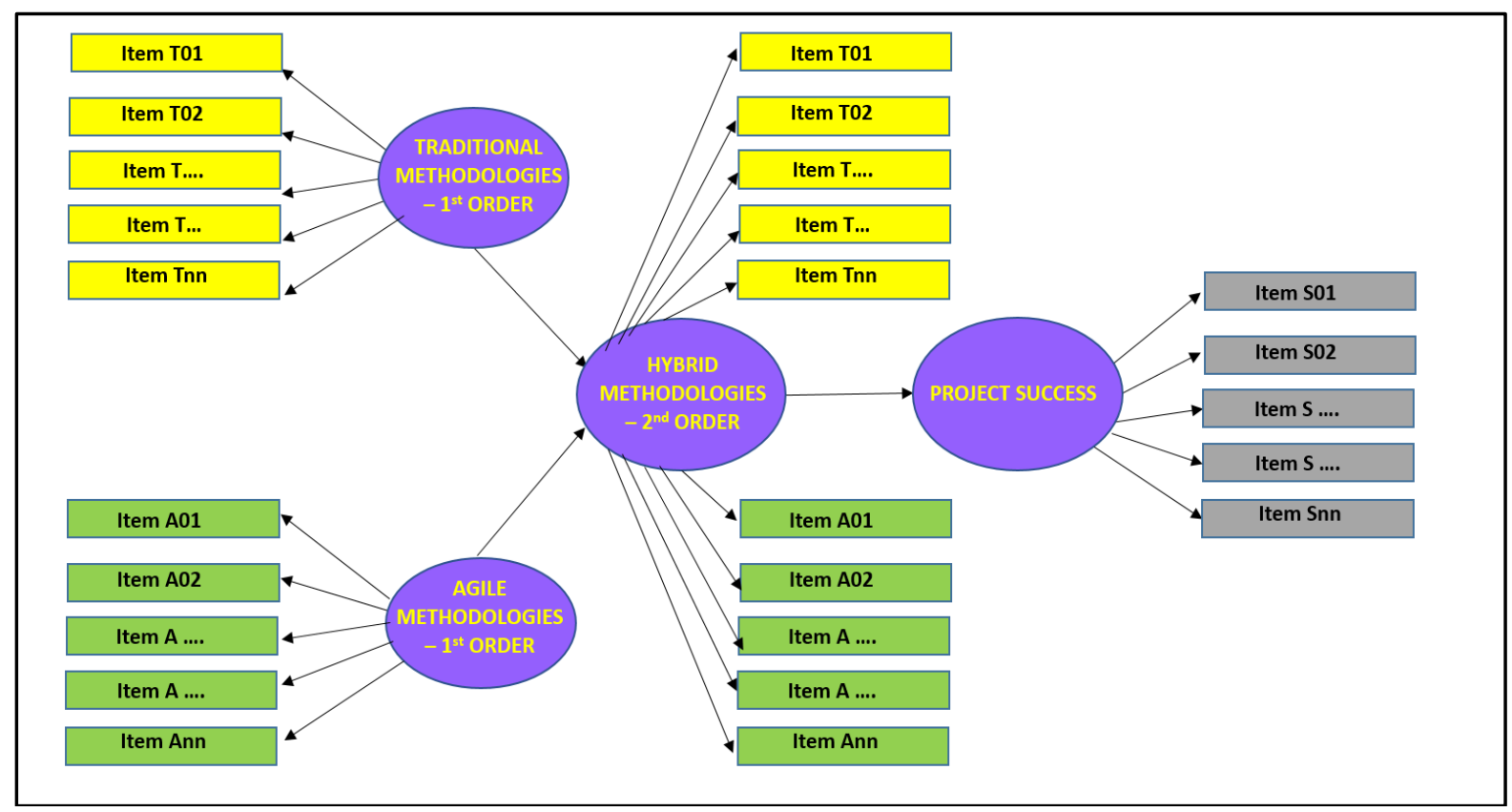

Figure 3. Repeatable components (items) for hybrid models

Data from 296 respondents for the various components (used as constructs) in the model were collected and a model fit was obtained using the SMART-PLStool. The hybrid component required the $1^{\text {st }}$ order and $2^{\text {nd }}$ order analysis to evaluate the model fit.

\section{Findings}

The analysis for a model-fit using SMART-PLS is provided in Table 4. A value of 1 for the hybrid component indicates that the items in traditional and agile methodologies are fully represented and provides a clear and accurate repeatition in the inclusion of the test and fits the model well. The project success component identifies that $75 \%$ of the indicators have attributed to the success from the hybrid components.

Table 4. Model-Fit Analysis

\begin{tabular}{ll}
\hline Components/Constructs & Model Fit \\
\hline HYBRID METHODOLOGIES & 1 \\
\hline PROJECT SUCCESS & 0.755 \\
\hline
\end{tabular}

\section{Conclusion}

The questionnaire design and the model fit analysis provides a good basis for researches that use hybrid model to have repeatable indicators and use $1^{\text {st }}$ and $2^{\text {nd }}$ order construct analysis to determine the model fit. As the data used in the analysis is a good sized sample for a specific interest target group, it is reasonable to suggest that a larger sample would increase the project successmodel fit percentage with more refined questions and further improve the model-fit analysis and values.

\section{Acknowledgment}

The authors would like to express gratitude for the financial support provided under the (Fundamental Research Grant Scheme) FRGS Cost Centre : 5540287.

\section{References}

1. Alwan, A. A., Ibrahim, H., Udzir, N. I., \& Sidi, F. (2016). An efficient approach for processing skyline queries in

2. Alwan, A. A., Ibrahim, H., Udzir, N. I., \& Sidi, F. (2017). Processing skyline queries in incomplete distributed databases. Journal of Intelligent Information Systems, 48(2), 399-420. doi:10.1007/s10844016-0419-2. 
3. Carvalho, W. C. D. S., Rosa, P. F., Soares, M. D. S., Cunha, M. A. T. Da, Buiatte, L. C., \& Da Cunha, M. A. T. (2012). A comparative analysis of the agile and traditional software development processes productivity. Proceedings - International Conference of the Chilean Computer Science Society, SCCC, 74-82. https://doi.org/10.1109/SCCC.2011.11

4. Conforto, E. C., Amaral, D. C., da Silva, S. L., Di Felippo, A., \& Kamikawachi, D. S. L. (2016). The agility construct on project management theory. International Journal of Project Management, 34(4), 660-674. https://doi.org/10.1016/j.ijproman.2016.01.007

5. Cooper, R. G. (2016). Agile-stage-gate hybrids. Research Technology Management, 59(1), 21-29. https://doi.org/10.1080/08956308.2016.1117317

6. Dao, B., Kermanshachi, S., Shane, J., Anderson, S., \& Hare, E. (2016). Identifying and Measuring Project Complexity. Procedia Engineering, 145, 476-482. https://doi.org/10.1016/j.proeng.2016.04.024

7. Davis, K. (2017). An empirical investigation into different stakeholder groups perception of project success. International Journal of Project Management, 35(4), 604-617. https://doi.org/10.1016/j.ijproman.2017.02.004

8. Eri, Z. D., Abdullah, R., Jabar, M. A., \& Murad, M. A. A. (2012). Virtual communities model using ontology of group classification for research communities. International Conference on Information Retrieval and Knowledge Management, CAMP'12, 126-130. doi:10.1109/InfRKM.2012.6205019

9. Escobar-Sarmiento, V., \& Linares-Vásquez, M. (2012). A model for measuring agility in small and medium software development enterprises. In 38th Latin America Conference on Informatics, CLEI 2012 - Conference Proceedings. https://doi.org/10.1109/CLEI.2012.6427226

10. Fontana, R. M., Meyer, V., Reinehr, S., \& Malucelli, A. (2015). Progressive Outcomes: A framework for maturing in agile software development. Journal of Systems and Software. https://doi.org/10.1016/j.jss.2014.12.032

11. Gheni, A. Y., Jusoh, Y. Y., Jabar, M. A., \& Ali, N. M. (2016). Factors affecting global virtual teams' performance in software projects. Journal of Theoretical and Applied Information Technology, 92(1), 90-97.

12. Gill, A. Q., Henderson-Sellers, B., \& Niazi, M. (2016). Scaling for agility: A reference model for hybrid traditional-agile software development methodologies. Information Systems Frontiers, 1-27. https://doi.org/10.1007/s10796-016-9672-8

13. Gregor, S. (2006). The nature of theory in Information Systems. MIS Quarterly: Management Information Systems, 30(3), 611-642. https://doi.org/10.2307/25148742incomplete multidimensional database. Arabian Journal for Science and Engineering, 41(8), 2927-2943. doi:10.1007/s13369-0162048-z.

14. Hussain, A., Mkpojiogu, E.O.C., Yusof, M.M. (2016). The effect of proposed software products' features on the satisfaction and dissatisfaction of potential customers. AIP Conference Proceedings, 1761, art. no. 020052.

15. Hussain, A., Mkpojiogu, E.O.C. (2016). Usability evaluation techniques in mobile commerce applications: A systematic review. AIP Conference Proceedings, 1761, art. no. 020049.

16. IskandarIshak, \& Sidi, Fatimah \& Jabar, Marzanah \& Sani, Nor Fazlida Mohd \& Mustapha, Aida \& Supian, S.R. \& Apau, M.N.. (2012). A survey on security awareness among social networking users in Malaysia. Australian Journal of Basic and Applied Sciences. 6. 23-29

17. Jabar, M. A., Khalefa, M. S., Abdullah, R. H., \& Abdullah, S. 2014. Meta-analysis of ontology software development process. International Review on Computers and Software, 9(1), 29-37.

18. Jørgensen, M. (2016). A survey on the characteristics of projects with success in delivering client benefits. Information and Software Technology. https://doi.org/10.1016/j.infsof.2016.05.008

19. Kuhrmann, M., Diebold, P., Munch, J., Tell, P., Trektere, K., Mc Caffery, F., ... Prause, C. (2018a). Hybrid Software Development Approaches in Practice: A European Perspective. IEEE Software. https://doi.org/10.1109/MS.2018.110161245

20. Kuhrmann, M., Diebold, P., Munch, J., Tell, P., Trektere, K., Mc Caffery, F., ... Prause, C. (2018b). Hybrid Software Development Approaches in Practice: A European Perspective. IEEE Early Access Articles. https://doi.org/10.1109/MS.2018.110161245

21. Miller, G. (2001). The Characteristics of Agile Software Processes. International Conferences and Exhibition on Technology of Object-Oriented Languages and Systems (TOOLS).

22. Nguyen, T. S., Mohamed, S., \& Panuwatwanich, K. (2018). Stakeholder Management in Complex Project: Review of Contemporary Literature. Journal of Engineering, Project, and Production Management, 8(2), 75-89. https://doi.org/10.32738/jeppm.201807.0003

23. Niknazar, P., \& Bourgault, M. (2017). Theories for classi fi cation vs . classi fi cation as theory: Implications of classi fi cation and typology for the development of project management theories, 35, 191-203.

24. Papadakis, E., \& Tsironis, L. (2018). Hybrid methods and practices associated with agile methods, 
method tailoring and delivery of projects in a non-software context. Procedia Computer Science, 138, 739-746. https://doi.org/10.1016/j.procs.2018.10.097

25. Papadopoulos, G. (2015). Moving from Traditional to Agile Software Development Methodologies Also on Large, Distributed Projects. Procedia - Social and Behavioral Sciences, 175, 455-463. https://doi.org/10.1016/j.sbspro.2015.01.1223

26. Qumer, A. (2008). A framework to support the evaluation, adoption and improvement of agile methods in practice. https://doi.org/10.1016/j.jss.2007.12.806

27. Rauf, A., \& AlGhafees, M. (2015). Gap Analysis between State of Practice and State of Art Practices in Agile Software Development. 2015 Agile Conference, 102-106. https://doi.org/10.1109/Agile.2015.21

28. Roopa S, M. R. (2012). Questionnaire Designing for a Survey. The Journal of Indian Orthodontic Society, 46(4), 273-377.

29. Saad, N. H. M., Ibrahim, H., Alwan, A. A., Sidi, F., \& Yaakob, R. (2014). A framework for evaluating skyline query over uncertain autonomous databases. Procedia Computer Science, 29 1546-1556. doi:10.1016/j.procs.2014.05.140.

30. Saad, N. H. M., Ibrahim, H., Sidi, F., Yaakob, R., \& Alwan, A. A. (2016). Computing range skyline query on uncertain dimension, doi:10.1007/978-3-319-44406-2_31.

31. Schelling, M., \& Pierling, L. (2015). Dynamic Capabilities within the Project Management Environment. Masters Thesis.

32. Serrador, P., \& Pinto, J. K. (2015). Does Agile work? - A quantitative analysis of agile project success. International Journal of Project Management, 33(5), 1040-1051. https://doi.org/10.1016/j.ijproman.2015.01.006

33. Sidi, F., Jabar, M.A., Mustapha, A., Sani, N.F., Ishak, I., \& Supian, S.R. (2013). Measuring computer security awareness on internet banking and shopping for internet users. Journal of Theoretical and Applied Information Technology, 53(2): 210-216.

34. Sidi, F., Marzanah, A. J., Affendey, L. S., Ishak, I., Sharef, N. M., Zolkepli, M., Tan Ming Ming, T. M., Abd Mokthi, M. F., Maslina Daud, Naqliyah Bt Zainuddin and Rafidah Abdul Hamid. (2017). A comparative analysis study on information security threat models: A propose for threat factor profiling. Journal of Engineering and Applied Sciences, 12(3), 548-554. doi:10.3923/jeasci.2017.548.554.

35. Spalek, S. (2016). Traditional Vs. Modern Project Management Methods. Theory and Practice. Smart and Efficient Economy: Preparation for the Future Innovative Economy, (May 2016), 499-506. Retrieved from \%3CGo\%0Ato

36. Takeomi Imani, Masaru Nakano, and V. A. (2017). Does a Hybrid Approach of Agile and Plan-Driven Methods Work Better for IT System Development Projects? Journal of Engineering Research and Applications, 7(3), 39-46. https://doi.org/10.9790/9622-0703043946

37. Theocharis, G., Kuhrmann, M., Münch, J., \& Diebold, P. (2016). Is Water-Scrum-Fall Reality? On the Use of Agile and Traditional Development Practices, 1-10. https://doi.org/Is Water-Scrum-Fall Reality? On the Use of Agile and Traditional Development Practices Georgios Theocharis, Marco Kuhrmann, Jürgen Münch, Philipp Diebold December 2015 PROFES 2015: Proceedings of the 16th International Conference on Product-Focused Software Process Improvement - Volume 9459 Publisher: SpringerVerlag New York, Inc.

38. Tripp, J. F. (2012). TThe Impacts of Agile Development Methodology Use on Project Success: A Contingency View.

39. Vedsmand, T., Kielgast, S., \& Cooper, R. G. (2016). Integrating Agile with Stage-Gate ${ }^{\circledR}-$ How New Agile-Scrum Methods Lead to Faster and Better Innovation. Innovationmanagement.Se, (August), 1-14. Retrieved from http://www.innovationmanagement.se/2016/08/09/integrating-agile-with-stage-gate/

40. Wells, H., Dalcher, D., \& Smyth, H. (2015). The adoption of agile management practices in a traditional project environment: An IT/IS case study. Proceedings of the Annual Hawaii International Conference on System Sciences, 2015-March, 4446-4453. https://doi.org/10.1109/HICSS.2015.532

41. Wilson, B., \& Henseler, J. (2007). Modeling Reflective Higher-Order Constructs using Three Approaches with PLS Path Modeling: A Monte Carlo Comparison. Conference Proceedings ANZMAC 2007, (January), 791-800. Retrieved from http://doc.utwente.nl/91758/

42. Wood, H. L., \& Ashton, P. (2010). The Factors of Project Complexity. CIB World Building Congress, , Salford, UK, 69-80.

43. Yang, S., Mao, X., Yang, S., \& Liu, Z. (2017). Towards a hybrid software architecture and multi-agent approach for autonomous robot software. International Journal of Advanced Robotic Systems, 14(4), 115. https://doi.org/10.1177/1729881417716088 